\title{
Case Study: \\ Potential Trademark Infringements
}

Michael Cosgrove, (Email: mcos@gsm.udallas.edu) University of Dallas

Daniel Marsh, (Email: dmarsh@gsm.udallas.edu) University of Dallas

J.F. Chester, (Email: jfchester@tradelawfirm.com), University of Dallas

\begin{abstract}
This is a case study of trademark infringement disputes. One of the authors (Cosgrove) incorporated The Econoclast, Inc. that owns a registered trademark (Econoclast $($ ) that has provided capital market publications to financial and nonfinancial institutions since 1979. Over the years, others have used the same name for similar services. The case study explains the basics of trademark law and the meaning of trademark infringement. The authors describe the practical steps Cosgrove undertook to prevent infringement of his trademark in three different situations. There remains an on-going dispute involving possible international infringement in one of the illustrations.
\end{abstract}

\section{INTRODUCTION}

$T$

he purpose of a trademark is to provide protection to consumers by ensuring that goods and services they purchase are actually manufactured or provided by the companies associated with the marks. By granting trademark owners the exclusive right to use certain marks to identify their goods and services, trademark law allows a firm to distinguish its product from that of other firms which is a method of branding. The value of a trademark to its owner is dependent on a number of factors such as the size of the market created for the branded product.

Trademark protection can arise through common law right by merely using the mark in commerce, or via registration at a national office. Both methods afford equal protection, although the requirements for obtaining and retaining protections, as well as the geographic limits of trademark rights are different for registered trademark owners versus owners of purely common law trademark rights. For registered marks, the period of protection varies, but a trademark can be renewed indefinitely beyond the time limit on payment of additional fees. Trademark protection is enforced by the courts, which in most countries have the authority to block trademark infringement.

Trademarks promote enterprise both locally and globally by providing owners of trademarks with recognition and profit. Trademark protection also hinders the efforts of unfair competitors, such as counterfeiters, to use similar distinctive signs to market their products and/or services. Trademark law allows people with skill and enterprise to produce and market goods and services more profitably, thereby facilitating both domestic and international trade. Moreover, trademarks can protect consumers from unwittingly paying a premium for inferior products.

Trademarks can be obtained on a variety of items. That may include a combination of words, letters, numerals, symbols, colors, and artwork. In addition to trademarks identifying the commercial source of goods or services, several other categories of marks exist. Collective marks are owned by an association whose members use them to identify themselves with a level of quality and other requirements set by the association. Examples of such associations would be those representing accountants and engineers. Also, certification marks such as Underwriters Laboratories or the Good Housekeeping Seal, are protected trademarks which are used to identify products which meet the specific standards of those certifying entities. 
A trademark is registered by filing an application with the appropriate national or regional trademark office. The application must contain a clear reproduction of the mark filed for registration, including any colors, forms, or three-dimensional features. The application must also contain a list of goods and/or services to which the sign would apply. The mark must fulfill certain conditions in order to be protected as a trademark or other type of mark. It must be distinctive, so that consumers can distinguish it as identifying a particular product, as well as from other trademarks identifying other products. It must neither mislead nor deceive customers or violate public order or morality.

In addition, trademark law recognizes the principle of priority. That is, the rights applied for cannot be the same as, or "confusingly similar" to, rights already granted to another trademark owner. Whether a mark is confusingly similar to a preexisting mark is determined through search and examination by the national office, or by the opposition of third parties who claim similar or identical rights.

Most countries in the world register and protect trademarks. Each national or regional office maintains a Register of Trademarks which contains full application information on all registrations and renewals, facilitating examination, search, and potential opposition by third parties. The effects of such a registration are, however, limited to the country (or, in the case of a regional registration, countries) concerned.

In order to avoid the need to register separately with each national or regional office, WIPO (The World Intellectual Property Organization) administers a system of international registration of marks. This system is governed by two treaties, the Madrid Agreement Concerning the International Registration of Marks and the Madrid Protocol. A person who is a resident of a country party to one or both of these treaties may, on the basis of a registration or application with the trademark office of that country, obtain an international registration having effect in some or all of the other countries of the Madrid Union. At present, more than 60 countries are party to one or both of the agreements. Although the U.S. has been a part of the Madrid Protocol for some time, the USPTO has only recently enacted procedures for handling Madrid Protocol applications.

This introduction to trademarks is taken, in part, from the World Intellectual Property Organization. Information on obtaining a trademark can be obtained from United States Patent and Trademark Office.

\section{FRAMEWORK FOR TRADEMARKS}

"The objective of intellectual property protection is to create incentives that maximize the difference between the value of the intellectual property that is created and used and the social cost of its creation, including the cost of administering the system" (Besen, 1991).

Intellectual property can be protected by patents, copyrights and trademarks. Trademark protection doesn't have a constitutional footing while patents and copyrights do. State law is the origin of trademarks; Federal trademark protection was passed in 1870 but that particular act was ruled unconstitutional. But in terms of history the Romans, Greeks and others used different markings to indicate who made items such as pottery or bricks. In the Middle Ages, trade guilds employed markings to identify who made a particular product. The 1946 Lanham Act is the basis of the modern U.S. Trademark system which spelled out the major requirements for registration and maintenance of ownership.

The purpose of trademark law is to prevent confusion in the minds of the consuming public as to the source of a particular good and/or service. The owner of a trademark has spent time and resources marketing goods and services identified by the mark. And the purpose of doing that is to have the mark identified with only those goods and services to the exclusion of other goods and services. In monopolistic competition, trademarks or branding can be very useful as a method to help differentiate close but imperfect substitutes. The trademark holder often must work to prevent others from using the trademark and benefiting from prior use of the trademark. Using someone else's trademark without permission, known as infringement, will likely cause confusion in the minds of the consuming public. 
It is not necessary to prove actual confusion of unique customers in order to prove trademark infringement. Proving likelihood of confusion in the market satisfies the requirement, so that similar marks in physical design could make the case for infringement (Besen, 1991).

A trademark does not need to be registered for the owner to prevent others from using it. But Federal registration does provide legal advantages to the trademark holder when pursuing infringers. One advantage is that it is a public notice, which prevents anyone from claiming that they did not know the mark existed. This notice is constructively assumed to be given to anyone within the territorial jurisdiction of the registering body. For example, a mark registered with the U.S. Patent \& Trademark Office would be constructive notice to anyone within the United States, plus its territories and protectorates.

Trademarks must be protected by the trademark holder to prevent them from falling into the public domain and causing the trademark holder to lose protection (Iowa State University). ). For example, the term "Kleenex" has become so ubiquitous that people often refer to non-Kleenex brand facial tissue as "Kleenex." If left unchecked, the mark could become synonymous with "facial tissue", and thus would become generic. If so, the mark loses its uniqueness, and would thus lose its protection under trademark law.

\section{CASE STUDY}

The Econoclast, Inc. was incorporated by Professor Cosgrove in 1979 and has provided capital market publications to institutions since that time. It is independent of the University of Dallas. Professor Cosgrove also has been a monthly contributor to Blue Chip Economic Indicators since 1983 as well as to the Western Blue Chip State Economic Forecast since1989. He has been a semiannual contributor to The Wall Street Journal economic outlook survey since 1994. Cosgrove also contributes to Barron's Interest Rate Outlook Survey, the Philadelphia Federal Reserve Economic Survey as well as the National Association of Business Economists Outlook Survey. In other words, Cosgrove has spent significant time and resources in developing customer recognition and goodwill in the Econoclast ${ }^{\circledR}$ mark.

\section{Likely Infringement Within The U.S.}

Red Herring (Red Herring) which covers "The Business of Technology," published a column on economic concepts written by David R. Henderson in 1998. From June 1998 (or perhaps earlier) to December 1998, Mr. Henderson used "Econoclast." In December 1998 in a column entitled The Voice of Choice, Mr. Henderson's first sentence was "In last month's Econoclast, I considered the phenomenon of the haves, those making.........

David R. Henderson is a research fellow with the Hoover Institution and an associate professor of economics at the Naval Postgraduate School in Monterey, California. Some of Mr. Henderson's writings were quoted in the Hoover Digest which made use of Cosgrove's trademark Econoclast ${ }^{\circledR}$. The following is such an example.

David Henderson, The Econoclast: A Communications Service, Red Herring, October 1998; Minimum Wage + \$1 = More Poverty, Fortune, October 12, 1998; Celebrate Your Wealth, Red Herring, November 1998; The Voice of Choice, Red Herring, December 1998; (Hoover Digest.)

This illustrates that potential infringement by one organization, Red Herring, resulted in the Hoover Digest also carrying Econoclast ${ }^{\circledR}$ which is a trademarked name.

Professor Cosgrove's actions in December 1998, when he discovered the infringement, were as follows:

He sent a cease and desist email to Red Herring on December 28, 1998 informing them that one of their writers, David R. Henderson, was infringing on Professor Cosgrove's trademark - registration number 1571263 - and to cease and desist. On the same day Professor Cosgrove sent a cease and desist email to David Henderson. Mr. Henderson emailed back the next day, December 29, with one sentence - "It sounds as if your issue is with the Red 
Herring, not with me. I have never used the term Econoclast." So editors at Red Herring must have altered Mr. Henderson's writing to include "Econoclast."

On January 5, 1999 Professor Cosgrove received an email from Red Herring stating that the matter had been referred to their trademark attorney - ...Ralph Francis of Francis Law Group. On January 7, 1999 Professor Cosgrove received a fax stating that "The purpose of this letter is to serve as notice that Red Herring Communications, Inc. (the company) has reviewed your registration for Econoclast and, as a courtesy to you, has decided to cease using Econoclast in any of its published material from the date of this letter forward."

\section{Illustration II - Likely Infringement within the U.S.}

In 2001 The Deal started using "Econoclast" as the name of a column on the company's website (Deal.) The Deal LLC is a media organization that provides financial information to investors.

Professor Cosgrove sent a cease and desist letter to The Deal on November 5, 2001 informing them that they were infringing on his trademark - Econoclast ${ }^{\circledR}$ - Fed Reg \# 1571263 and that this trademark had been held since 1989. Louis Willacy of The Deal responded on November 12, 2001 and made the argument that their use of Econoclast didn't impinge on Professor Cosgrove's trademark as they were using it in connection with financial goods and services while his use was economic services and concluded that "we do not believe there is any reasonable likelihood of confusion between the respective trademarks."

At that point Professor Cosgrove found it necessary to employ a law firm to contact The Deal. A representative of the law firm sent a cease and desist letter to The Deal on December 11, 2001. There are a number of cases that help clarify the confusingly similar aspects of a mark.

The Court in In re E. I. DuPont de Nemours \& Co., 476 F.2d 1357, 177 USPQ 563 (C.C.P.A. 1973), listed the principal factors to consider in determining whether there is a likelihood of confusion. Among these factors are the similarity of the marks as to appearance, sound, meaning and commercial impression, and the relatedness of the goods and/or services. The overriding concern is to prevent buyer confusion as to the source of the goods and/or services. Miss Universe, Inc. v. Miss Teen U.S.A., Inc., 209 USPQ 698 (N.D. Ga. 1980). Therefore, any doubt as to the existence of a likelihood of confusion must be resolved in favor of the registrant. In re Hyper Shoppes (Ohio), Inc., 837 F.2d 463, 6 USPQ2d 1025 (Fed. Cir. 1988); Lone Star Mfg. Co. v. Bill Beasley, Inc., 498 F.2d 906, 182 USPQ 368 (C.C.P.A. 1974).

A likelihood of confusion determination requires a two-part analysis. First the marks are compared for similarities in appearance, sound, connotation and commercial impression. In re E. I. DuPont de Nemours \& Co., 476 F.2d 1357, 177 USPQ 563 (C.C.P.A. 1973). Second, the goods or services are compared to determine whether they are similar or related or whether the activities surrounding their marketing are such that confusion as to origin is likely. In re August Storck KG, 218 USPQ 823 (TTAB 1983); In re Int'l Tel. and Tel. Corp., 197 USPQ 910 (TTAB 1978); Guardian Prods. Co., v. Scott Paper Co., 200 USPQ 738 (TTAB 1978); TMEP $\S 1207.01$ et seq.

The goods and/or services of the parties need not be identical or directly competitive to find a likelihood of confusion. Instead, they need only be related in some manner, or the conditions surrounding their marketing be such that they could be encountered by the same purchasers under circumstances that could give rise to the mistaken belief that the goods and/or services come from a common source. In re Martin's Famous Pastry Shoppe, Inc., 748 F.2d 1565, 223 USPQ 1289 (Fed. Cir. 1984); In re Melville Corp., 18 USPQ2d 1386, 1388 (TTAB 1991); In re Corning Glass Works, 229 USPQ 65 (TTAB 1985); In re Rexel Inc., 223 USPQ 830 (TTAB 1984); Guardian Prods. Co., Inc. v. Scott Paper Co., 200 USPQ 738 (TTAB 1978); In re Int'l Tel. \& Tel. Corp., 197 USPQ 910 (TTAB 1978); TMEP $\S 1207.01(\mathrm{a})(\mathrm{i})$. 
At a later date a representative of The Deal sent a letter stating The Deal did agree to cease and desist.

After that incident, Professor Cosgrove's legal representative suggested he apply for a trademark in a different class, Class 16, and include the term "financial publications." That Econoclast ${ }^{\circledR}$ trademark $-2,680,571$ was registered on January 28, 2003.

In the Red Herring infringement Professor Cosgrove was able to have the party agree to stop using his trademark -- Econoclast ${ }^{\circledR}$-- with a minimum of transaction costs. There have been several other minor infringement cases like the Red Herring in which a cease and desist letter from Professor Cosgrove stopped the party from further use of his trademark. However in the infringement case of The Deal, the transaction cost increased considerably since Cosgrove needed to employ legal counsel.

This is one of the difficulties of protecting trademark rights. Although the USPTO will buttress the rights of registered trademark owners, it will not police the world - or even the United States - for possible infringers; nor will the USPTO advance a case in court on behalf of trademark owners. Rather, it is the responsibility of trademark owners to be vigilant in ensuring that their mark is not being infringed, and to bear the burden of asserting their rights. One exception to this limitation is with regards to trademarks on goods imported into the U.S. Provided the trademark is registered with U.S. Customs and Border Protection (CBP), CBP will not allow any goods bearing such marks to enter the U.S. unless they are (1) being imported by the trademark owner, or (2) accompanied by a copy of a license agreement.

\section{Illustration III - Possible International and Likely U.S. Infringement}

Dr. John Palmer, a professor at the University of Western Ontario, started a blog on economics called "Econoclast." U.S. trademark law does not apply in Canada so legally Professor Cosgrove had no recourse, but Dr Palmer was sent a cease and desist letter. The question in this case is whether Dr Palmer felt he had a moral duty not to engage in trademark infringement, even if he did not have a legal duty. He subsequently changed the name of his blog to "The Eclectic Econoclast" but that does not alter the trademark confusion issue on Econoclast ${ }^{\circledR}$. But again U.S. trademark law does not apply in Canada.

This situation introduces an interesting legal issue. The internet is essentially a global village in which national borders become meaningless, yet laws defining intellectual property rights can only be enforced within national jurisdictions. Even though U.S. trademark law is not applicable in Canada, residents of the U.S. can access the site in Canada and Econoclast ${ }^{\circledR}$ is a registered trademark in the U.S. Since Econoclast ${ }^{\circ}$ is available via the internet, the mark, in one sense, has already been published in Canada. Thus, it may be possible that Canadian Law could afford some protection to Econoclast ${ }^{\circledR}$ under Canadian common law.

In addition the USPTO considers web pages to be valid evidence of "use in commerce" for purposes of applying for Federal Trademark Registration. However the question remains as to the geographic limits of this "use in commerce."

A far more troubling and potentially much more significant case of trademark infringement arose when the American Economic Association's website Resources for Economists started hosting a link to the Econoclast site in Canada listed as "Econoclast." The following is what the American Economic Association carried (AEA, Econoclast).

We as professors naturally discuss with students the importance of respecting intellectual property and following ethical standards, so as to ensure students do not engage in plagiarism. So while mildly surprised by the behavior of the Canadian Dr Palmer, Professor Cosgrove was extremely surprised to find that his trademark was being violated by the American Economic Association. Professor Cosgrove is a longtime member of the AEA, and so it was extremely surprising to Professor Cosgrove that his professional association was violating a member's trademark. The AEA presents itself as the public spokesman for academic economists in the United States, and normally adheres to the highest ethical and intellectual standards. 


\section{Exhibit I}
- AEA Web
- RFE Search
- Conferences
- $\quad$ Complete Contents
- $\quad$ Abridged Contents

Tables of Contents: Abridged | Complete

Search RFE

$\underline{\text { Title Page / Blogs and Commentaries }}$

\section{Econoclast}

This blog is written by John Palmer of the University of Western Ontario. It covers a variety of economic topics.

$\square$ http://the-econoclast.blogspot.com/

The AEA, based in the United States, hosted a link to the Canadian Econoclast site which meant that the American Economic Association appeared to be infringing a U.S. trademark. A cease and desist email was sent to William Goffe, Editor of Resources for Economists on January 9, 2005 with copies to some of the present and past officers of the AEA including Martin Feldstein, George Akerlof, Robert Hall, Janet Yellen and Alan Krueger. As of May 2, 2005 Professor Cosgrove had not received a response from anyone at the AEA. Again this is somewhat surprising.

On May 2, 2005 the AEA Blogs and Commentaries page still had the following listed - this is a partial listing of that page (AEA Blogs.)

\section{Exhibit 2}

\section{$\underline{\text { Title Page / Blogs and Commentaries }}$}

\section{Blogs and Commentaries}

Blogs (from "web logs") are frequent (often daily) commentaries on almost any possible issue. These blogs cover a variety of economic issues; the topics tend to be either policy or education oriented. This section also includes commentaries on economic issues from non-blogs.

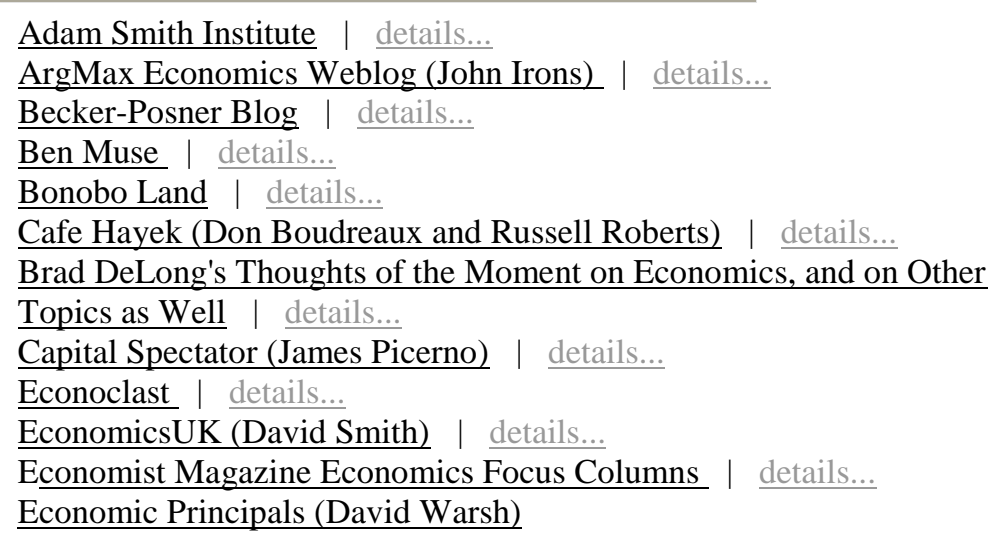


We can only speculate as to what the officers of the AEA are thinking about this issue, or whether they are thinking about it at all. Are they ignoring this issue because they regard it as trivial or inconsequential? Of course, as educators at prestigious American universities, they have many demands on their time. But even students are expected to do a Google search to avoid the possibility of plagiarism and/or a copyright/trademark violation before submitting term papers. What level of due diligence does the AEA consider appropriate before adding links to its website? This is unclear.

The dispute with the American Economic Association was resolved on May 13, 2005 when the AEA removed the link to Mr. Palmer's site on the internet at rfe.org in response to Professor Cosgrove sending a follow-up email.

\section{SUMMARY}

Trademarks are a form of intellectual property similar to patents and copyrights. Infringement of trademarks is a violation of property rights under U.S. law and international conventions. One of the authors (Cosgrove) incorporated The Econoclast which owns the trademarked name Econoclast ${ }^{\circledR}$, the title of his capital markets service. A number of apparently inadvertent infringements of this trademark have occurred over the years. Most infringements were halted at low cost with cease-and-desist email letters. At the time of this writing, the dispute involving the Canadian website had not been resolved.

\section{REFERENCES}

1. American Economic Association Blogs and Commentaries site -http://rfe.org/showCat.php?cat_id=96

2. American Economic Association Executive Committee, Minutes of the Meeting of the Executive Committee in Philadelphia, PA, January 6, 2005, http://www.vanderbilt.edu/AEA/Jan605minExec.htm

3. Besen, Stanley M. and Raskind, Leo J., An Introduction to the Law and Economics of Intellectual Property, The Journal of Economic Perspectives, Vol. 5, (1), 1991, 2-27.

4. Hoover Institute -- http://www.hooverdigest.org/992/biblio.html

5. Iowa State University -- http://www.trademark.iastate.edu/basics/

6. Red Herring -- http://www.redherring.com/

7. The Deal LLP -- http://www.thedeal.com

8. United States Patent and Trademark Office, http://www.uspto.gov/index.html

9. World Intellectual Property Organization -- http://www.wipo.int/about-ip/en/trademarks.html 
NOTES 